\title{
Selenate Reduction and Selenium Enrichment of Tea by the Endophytic Herbaspirillum sp. Strain WT00C
}

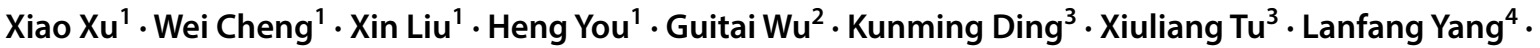 \\ Youpin Wang ${ }^{5} \cdot$ Yadong $\mathrm{Li}^{1} \cdot$ Haoshuang $\mathrm{Gu}^{2} \cdot \mathrm{Xin}$ gguo Wang ${ }^{1}$
}

Received: 26 March 2018 / Accepted: 1 April 2019 / Published online: 8 April 2019

(c) The Author(s) 2019

\begin{abstract}
Herbaspirillum sp. WT00C is a tea-plant-specific endophytic bacterium. A genomic survey revealed an intact pathway for selenocompound metabolism in the genome of this bacterium. When it was cultured with sodium selenate, Herbaspirillum sp. WT00C was able to turn the culture medium to red. Electron microscopy and energy-dispersive X-ray spectroscopy confirmed that Herbaspirillum sp. WT00C reduced selenite $\left(\mathrm{Se}^{6+}\right)$ to elemental selenium $\left(\mathrm{Se}^{0}\right)$, and selenium nanoparticles (SeNPs) were secreted outside bacterial cells and grew increasingly larger to form Se-nanospheres and finally crystallized to form selenoflowers. Biochemical assays showed that selenospheres contained proteins but not carbohydrates or lipids. The improvement of selenium enrichment of tea plants by Herbaspirillum sp. WT00C was also tested. After Herbaspirillum sp. WT00C was inoculated into tea seedlings via needle injection and soaking tea-cutting methods, this endophytic bacterium markedly enhanced selenium enrichment of tea. When the tea seedlings inoculated by soaking tea-cutting mode were cultivated in the selenium-containing soils, selenium contents of tea leaves in three experimental groups were more than twofold compared to those of control groups. Our study demonstrates that the endophytic bacterium Herbaspirillum sp. WT00C has the ability to reduce selenate and improve selenium enrichment of tea.
\end{abstract}

Xingguo Wang

xgwang@hubu.edu.cn

$\mathrm{Xiao} \mathrm{Xu}$

693080778@qq.com

Wei Cheng

451396909@qq.com

Xin Liu

liuxinhub@163.com

Heng You

459894090@qq.com

Guitai Wu

704457501@qq.com

Kunming Ding

1057660714@qq.com

Xiuliang Tu

tx18256437@163.com

Lanfang Yang

122828153@qq.com
Youpin Wang

ypwang7485@263.net

Yadong Li

lyd555@hotmail.com

Haoshuang $\mathrm{Gu}$

guhsh@hubu.edu.cn

1 The Faculty of Life Science, Hubei University, Wuhan, China

2 The Faculty of Physics and Electronic Sciences, Hubei University, Wuhan, China

3 Xianning Academy of Agricultural Science, Xianning, Hubei, China

4 The Faculty of Resource and Environmental Science, Hubei University, Wuhan, China

5 Hubei Academy of Agricultural Science, Wuhan, China 


\section{Introduction}

Selenium is well known as an essential trace element for both plants and mammals. Typically, selenium exists as selenate and selenite oxoanions in soil. Plants can absorb selenium directly from soil via roots. Low doses of selenium can stimulate the growth of plants, whereas at high dosages, it can cause plant damage [1-3]. Mammals only obtain selenium indirectly through food. In both plants and mammals, selenium compounds are typically metabolized into selenocysteine and selenomethionine. The deficiency of selenium is thought to be associated with over 40 human diseases $[4,5]$, and selenium has also been shown to be effective against cancers [6, 7].

Many bacterial species have been observed to reduce selenate/selenite to red elemental selenium [8-13]. The detoxification of selenates/selenites to nontoxic elemental selenium was catalyzed by microbes, and the reverse process occurs slowly. This redox process is both time and concentration dependent [14]. Different bacterial strains reduce selenate/selenite to selenium nanoparticles under different conditions, including aerobic and anaerobic conditions [15-18]. Different types of selenium nanoparticles have been synthesized using proteins, peptides, and several other reducing agents [11, 14, 19]. However, a detailed mechanism for the formation and transformation of selenium nanospheres has not been fully elucidated.

Camellia sinensis (L.) is native to East, South, and Southeast Asia, and is currently cultivated in tropical and subtropical regions worldwide. Epidemiological observations and laboratory studies indicate that polyphenolic compounds present in tea may reduce the risk of a variety of illnesses, including cancer and coronary heart disease [20]. Animal model studies show that tea consumption protects against lung, forestomach, esophagus, duodenum, pancreas, liver, breast, colon, and skin cancers induced by chemical carcinogens [21-25]. Green tea consumption also has preventive effects against atherosclerosis and coronary heart disease, high blood cholesterol, and high blood pressure [26-28]. Selenium is an essential trace element that has a close relationship with cancers, hypertension, metabolic syndrome, diabetes, and other types of diseases due to its biological functions, such as in antioxidation, thyroid metabolism, protein folding, redox signaling, and immune system activation [29]. Thus, selenium-rich tea has received increased attention recently. However, most lands have selenium-poor soil, and the selenium content in agronomic crops is quite low $(<0.1 \mathrm{mg} / \mathrm{kg})$. Only in selenium-rich areas or in tea gardens that have applied selenite fertilizer or selenite directly via foliage sprays, the selenium content in tea leaves approach more than $0.25 \mathrm{mg} / \mathrm{kg}$. Even in the so-called high-selenium-enriched tea, the selenium content is only approximately $5 \mathrm{mg} / \mathrm{kg}$, which is too low for using as dietary supplement in humans. How to further improve the selenium content of tea remains an unsolved issue.

Herbaspirillum sp. WT00C, which was isolated from Camellia sinensis L and classified as a novel member of the genus Herbaspirillum, was able to grow slowly in nutrient broth (NB) or Luria-Bertani (LB) medium under laboratory conditions [30]. This bacterium entered into plants via traumatic infection and colonized only in tea plants without any disease symptoms [31]. Unlike $H$. seropedicae, $H$. rubrisubalbicans, and $H$. lusitanum which were able to fix nitrogen [32-34], Herbaspirillum sp. WT00C did not exhibit nitrogenfixing activity, and did not colonize in other crops, such as Brassica campestris, Brassica rapa, Oryza sativa, and Triticumaestivum [31]. Similar to $H$. seropedicae, H. rubrisubalbicans, and $H$. lusitanum, this tea-specific endophytic bacterium was also observed to produce indole-3-acetic acid (IAA), ammonia and siderophores [30,31], which was thought to play a role in inducing adventitious formation in dicots or monocots and improving plant growth and development [32-36]. Laboratory and field studies showed Herbaspirillum sp. WT00C indeed promoted lateral root formation and bud growth of tea cuttings and improved the growth of tea plants in field experiments. Thus, it was suggested that Herbaspirillum sp. WT00C could be developed as a plant growth-promoting agent used specifically for tea cultivation [31]. The genome of Herbaspirillum sp. WT00C was sequenced [37] and deposited in GenBank (Acc\#: MIJG00000000). In this study, we identified a pathway for selenocompound metabolism through investigation of its genome, in which selenate and selenite can be reduced to zerovalent selenium or incorporated into proteins through selenocysteine or selenomethionine. Next, we examined the process of selenate reduction in detail and confirmed that this bacterium indeed reduced selenate to elemental selenium and produced selenium nanospheres outside of bacterial cells. We hypothesized that the selenium reduction and metabolic capabilities of Herbaspirillum sp. WT00C might improve the selenium enrichment of tea when the bacterium colonized inside tea plants. To test this hypothesis, we inoculated the bacterium into tea plants via either needle injection or soaking tea cuttings. The results obtained from both methods provided convincing evidence that Herbaspirillum sp. WT00C significantly improved the selenium enrichment of tea. Meanwhile, a plausible mechanism for this observation was also suggested.

\section{Materials and Methods}

\section{Bacterial Strain and Culture}

Herbaspirillum sp. WT00C, an endophytic bacterium, was isolated by our laboratory from an ornamental tea 
plant (Camellia sinensis L.) in the moshan scenic spot of Wuhan city and classified as a novel member in the genus Herbaspirillum [30]. A brief description of bacterial isolation and identification is given below, the conventional endophyte isolation was performed by clearing the teaplant samples with water, sterilizing with $75 \%$ alcohol for $1 \mathrm{~min}$ and then $1 \%$ mercury bichloride for $3 \mathrm{~min}$, and finally washing 3-5 times with sterilized $\mathrm{dH}_{2} \mathrm{O}$. Then the sterilized sample was cut into $3 \times 3 \mathrm{~cm}$ tissue blocks, and cultured on nutrient agar (NA) containing $0.3 \%$ beef extract, $1 \%$ peptone, $0.5 \% \mathrm{NaCl}, 1.5 \%$ agar, with $\mathrm{pH} 7.5$ at $28{ }^{\circ} \mathrm{C}$ for $48 \mathrm{~h}$. The organisms isolated from Camellia sinensis L. were diluted and spread on the NA plates, and cultivated at $28{ }^{\circ} \mathrm{C}$ for $48 \mathrm{~h}$. All colonies obtained from the plates were transferred into fresh NA plates and incubated for another $48 \mathrm{~h}$ at $28{ }^{\circ} \mathrm{C}$, in which a round, opaque, milky white, surface-raised, neat-edge colony was selected. Subcultivation was performed in nutrient broth $(\mathrm{NB}, 0.3 \%$ beef extract, $1 \%$ peptone, $0.5 \% \mathrm{NaCl}$, $\mathrm{pH} 7.5$ ) at $28{ }^{\circ} \mathrm{C}$ for $48 \mathrm{~h}$, and the isolated strain was named as the strain WT00C [30]. Its 16S rRNA gene sequence (MK119980) shared 98-99\% homologous similarity with those strains in Herbaspirillum genus, and phylogenetic analysis also showed that the strain WT00C was affiliated with the genus Herbaspirillum [30]. The strain WT00C was Gram-negative, micro-aerobic, rodshaped, $1.4-1.8 \mu \mathrm{m}$ in length and $0.5-0.7 \mu \mathrm{m}$ in width, polar flagellum, and nonpigmented. Colonies growing on NB or Luria-Bertani (LB) agar were round, convex, opaque, milky white, surface raised, and had neat edges. Growth occurred up to $40{ }^{\circ} \mathrm{C}$ in $\mathrm{pH} 5.0-8.0$ and $0-1.5 \%(\mathrm{w} / \mathrm{v}) \mathrm{NaCl}$. Cells, producing indoleacetic acid (IAA), ammonia, and siderophore, were weakly resistant against $10 \mu \mathrm{g} / \mathrm{mL}$ penicillin and $5 \mu \mathrm{g} / \mathrm{mL}$ spectinomycin, but susceptible to chloramphenicol, tetracycline, gentamicin, kanamycin, erythromycin, and streptomycin [30]. The strain WT00C, detected by APIZYM25200 (BioMérieux) according to the manufacturer's instruction, also displayed enzymatic activities of alkaline phosphatase, esterase (C4), esterase lipase (C8), leucine arylamidase, valine arylamidase, acid phosphatase, and naphthol-AS-BI-phosphohydrolase.

This bacterium was routinely cultured in NB or LB medium. At first, the strain WT00C was picked from $-80{ }^{\circ} \mathrm{C}$ stock culture and streak inoculated on the NA plate containing $5 \mu \mathrm{g} / \mathrm{mL}$ spectinomycin and $10 \mu \mathrm{g} / \mathrm{mL}$ ampicillin, and then incubated at $37^{\circ} \mathrm{C}$ overnight. Single colony was inoculated into $5 \mathrm{~mL}$ NB medium supplemented with $5 \mu \mathrm{g} / \mathrm{mL}$ spectinomycin and $10 \mu \mathrm{g} / \mathrm{mL}$ ampicillin. After incubation at $37{ }^{\circ} \mathrm{C}$ overnight, the culture was transferred into fresh $\mathrm{LB}$ medium at an inoculation ratio of $1: 100$ and grown at $37^{\circ} \mathrm{C}$ as described previously $[30,31]$.

\section{Tests of Selenate Reduction}

Three methods were used to test the selenate reduction of Herbaspirillum sp. WT00C. Before the test of selenate reduction, the strain WT00C was first picked from $-80{ }^{\circ} \mathrm{C}$ store culture and streak-inoculated on the NA plate containing $5 \mu \mathrm{g} / \mathrm{mL}$ spectinomycin and $10 \mu \mathrm{g} / \mathrm{mL}$ ampicillin, and then incubated at $37{ }^{\circ} \mathrm{C}$ overnight. Single colony was picked and inoculated into $5 \mathrm{~mL}$ NB broth supplemented with $5 \mu \mathrm{g} / \mathrm{mL}$ spectinomycin and ampicillin, and then incubated at $37{ }^{\circ} \mathrm{C}$ overnight for bacterial activation. Second, three methods were used to examine if the activated bacterial cells were the strain WT00C: (1) The bacterial cells were stained with Gram-staining kit (Sigma-Aldrich) and then cell size, morphology, and Gram-staining were observed under a microscope (Dianying, DYS-106); (2) IAA production and antibiotic susceptibility were tested as described previously [30, 31]; and (3) The enzymatic profile was examined by API ZYM25200 (BioMérieux) according to the manufacturer's instruction. To test the selenate reduction, the bacterial culture was spread on six LB plates containing $5 \mu \mathrm{g} /$ $\mathrm{mL}$ spectinomycin, $10 \mu \mathrm{g} / \mathrm{mL}$ ampicillin, and 0 or $25 \mathrm{mM}$ sodium selenate after identification of the activated bacterial cells. Three LB plates without addition of sodium selenate were used as control. After incubation at $37^{\circ} \mathrm{C}$ for $24 \mathrm{~h}$, the color of bacterial colonies was observed and recorded by photography. Meanwhile, color change was also observed in LB broth. The activated bacterial cells were inoculated with the ratio of 1:100 into six flasks containing $200 \mathrm{~mL}$ fresh LB medium containing $5 \mu \mathrm{g} / \mathrm{mL}$ spectinomycin and $10 \mu \mathrm{g} / \mathrm{mL}$ ampicillin, in which three flasks were supplemented with $200 \mathrm{mM}$ sodium selenate and another set of 3 flasks without addition of sodium selenate, which were used as control. All flasks were incubated at $37^{\circ} \mathrm{C}$, at $200 \mathrm{rpm}$ for $24 \mathrm{~h}$. The color of bacterial cultures was observed and recorded by photography.

Selenate depletion and selenite formation were examined by means of Hydride-generation atomic fluorescence spectrometer (AFS200, Skyray Instrument Inc.). The overnight-activated bacterial cells were inoculated into $10 \mathrm{~mL}$ LB broth supplemented with $5 \mu \mathrm{g} / \mathrm{mL}$ spectinomycin and $10 \mu \mathrm{g} / \mathrm{mL}$ ampicillin, and then incubated at $37^{\circ} \mathrm{C}$ until $\mathrm{OD}_{600}$ reached 0.8 . Then, $0.1 \mathrm{~mL}$ of the bacterial culture was transferred to $10 \mathrm{~mL} \mathrm{LB}$ medium, containing $5 \mu \mathrm{g} /$ $\mathrm{mL}$ spectinomycin, $10 \mu \mathrm{g} / \mathrm{mL}$ ampicillin, and $1 \mathrm{mg} / \mathrm{mL}$ sodium selenate, and incubated at $37{ }^{\circ} \mathrm{C}$, at $200 \mathrm{rpm}$ for $0,2,5,10$, and $15 \mathrm{~h}$. Bacterial cultures were, respectively, centrifuged at $6000 \times g, 4{ }^{\circ} \mathrm{C}$ for $15 \mathrm{~min}$. After centrifugation, the pellet was removed away, and only the supernatant was collected. The supernatants collected at different incubation times were divided into two parts: one was used for the determination of total selenium content, and the other for selenite determination. Sample preparation 
and selenium measurement were performed according to the National standards of the People's Republic of China (GB 5009.93). In brief, $10 \mathrm{ml}$ of the supernatant for each sample was poured into a beakerflask, and heated on a graphite heating plate at $180{ }^{\circ} \mathrm{C}$ until $2 \mathrm{~mL}$ residual solution left. After the flask was cooled, $10 \mathrm{~mL}$ of the mixed acid solution (1 nitric acid: 4 perchloric acid) was added, mixed, and allowed to stand at room temperature overnight, and then the flask was heated to $180^{\circ} \mathrm{C}$ again. When the flask was cooled, $10 \mathrm{ml} 6 \mathrm{M} \mathrm{HCl}$ was added, and then the standing and heating processes described above were executed again. The solution in the flask was transferred to a $25-\mathrm{mL}$ volumetric flask, and the capacity was made up to $25 \mathrm{~mL}$ with ultrapure water. $5 \mathrm{~mL}$ solution was taken and transferred to another $25-\mathrm{mL}$ volumetric flask, where $1 \mathrm{~mL} 10 \mathrm{mg} / \mathrm{mL}$ potassium ferricyanide and $2 \mathrm{~mL} 18 \%$ $\mathrm{HCl}$ were added and then the capacity made up to $25 \mathrm{~mL}$. Those samples prepared above were used for determining total selenium content. The procedure of sample preparation for selenite $\left(\mathrm{SeO}_{3}{ }^{2-}\right)$ determination was similar to that for total selenium measurement except for two steps of acid treatments with boiling. Each sample, the carrier $(4 \%$ $\mathrm{HCl})$, and the reducer $(0.5 \%$ potassium hydrate and $1.5 \%$ potassium borohydride) were, respectively, loaded into AFS200 via autoloaders, and measurements and data collections were performed according to the manufacturer's instruction. Measurement for each sample was repeated three times. Selenium content was finally calculated based on the standard curve which was prepared by the selenium standard purchased from Tanmo standard substance Center (Beijing). Selenate residue content was calculated based on the Eq. 1.

Selenate residue $(\mathrm{mg} / \mathrm{ml})$

$$
\begin{gathered}
=\text { the total selenium measured }(\mathrm{mg} / \mathrm{ml}) \\
- \text { the selenite measured }(\mathrm{mg} / \mathrm{ml})
\end{gathered}
$$

\section{Transmission Electron Microscopy (TEM)}

Herbaspirillum sp. WT00C was grown in $25 \mathrm{~mL}$ LB broth containing $200 \mathrm{mM}$ selenate at $37{ }^{\circ} \mathrm{C}$ for $0,5,7,10,15$, 20 , and $24 \mathrm{~h}$. The bacterial cultures were then diluted 20 -folds with phosphate buffer ( $200 \mathrm{mM}, \mathrm{pH} 7.2)$. Next, the diluted cultures were aliquoted onto a formvar carbon support film, which was incubated at room temperature for several hours to allow for water evaporation. Finally, the samples were observed under a Tecnai $\mathrm{G}^{2} 20$ transmission electron microscope (FEI, USA) at $200 \mathrm{kV}$.

\section{Scanning Electron Microscopy (SEM)}

SEM was used to observe bacterial cells and SeNPs as reported by Li et al. [38]. In brief, Herbaspirillum sp.
WT00C was grown in $25 \mathrm{~mL}$ LB broth containing $200 \mathrm{mM}$ selenate at $37{ }^{\circ} \mathrm{C}$ for 12,24 , or $48 \mathrm{~h}$. The bacterial cultures were centrifuged at $6000 \times g$ for $15 \mathrm{~min}$, and the pellets were fixed in $2.5 \%$ glutaraldehyde for $30 \mathrm{~min}$, rinsed 3 times in $100 \mathrm{mM}$ phosphate buffer ( $\mathrm{pH} 7.2$ ), and dehydrated in an ethanol series (50, 70, 90, and 100\% ethanol). The ethanol was then displaced by isoamyl acetate, and the samples were mounted onto microscope slides and dried using a BAL-TEC CPD030 critical point drying apparatus. Finally, the samples were sputter-coated with gold to a thickness of approximately $20 \mathrm{~nm}$ and observed under a JSM7100F scanning electron microscope (JEOF, Tokyo, Japan).

\section{X-ray Diffraction Analysis}

Herbaspirillum sp. WT00C was cultured in $50 \mathrm{~mL}$ LB broth containing 50 or $200 \mathrm{mM}$ selenate at $37^{\circ} \mathrm{C}$ for $24 \mathrm{~h}$, after which the cultures were centrifuged at $6000 \times g$ and $4{ }^{\circ} \mathrm{C}$ for $20 \mathrm{~min}$. The supernatants were discarded, and the pellets containing bacterial cells and SeNPs were resuspended in $50 \mathrm{mM}$ Tris- $\mathrm{HCl}(\mathrm{pH} 7.5)$ and then centrifuged again, with this washing step repeated twice. The pellets were collected, freeze-dried in a LGJ-10 vacuum freeze dryer (Songyuan Beijing), and ground to fine particles with a diameter of $40 \mu \mathrm{m}$. Finally, the powdered samples were analyzed using a D8A25 X-ray diffractometer (Bruker, Germany) using $\mathrm{Cu} \mathrm{K} \alpha$ radiation $(\lambda=1.5406 \AA)$ in the range of $5^{\circ}$ to $80^{\circ}$ at $40 \mathrm{kV}$.

\section{Selenate Reduction in Cytoplasmic and Cell-Debris Protein Fractions}

Herbaspirillum sp. WT00C was cultured in LB broth at $37^{\circ} \mathrm{C}$ for $15 \mathrm{~h}$. When the $\mathrm{OD}_{600}$ value approached to 1.0 , the cells were harvested by centrifugation at $800 \times g, 4{ }^{\circ} \mathrm{C}$ for $15 \mathrm{~min}$. Next, the cells were resuspended in PBS ( $\mathrm{pH}$ 7.2) and washed and centrifuged at $4{ }^{\circ} \mathrm{C}$ three times with the same buffer to remove the entire LB medium. The bacterial cells in PBS (pH 7.2) were sonicated, and the supernatant and the pellet were separated by centrifuging at $10,000 \times g$, $4{ }^{\circ} \mathrm{C}$ for $20 \mathrm{~min}$. The cytoplasmic protein-containing supernatant was collected, and the membrane protein-containing pellet was dissolved in PBS ( $\mathrm{pH}$ 7.2). Protein concentrations were determined using the Bradford method [39]. Equal amount of proteins $(0.3 \mathrm{mg} / \mathrm{mL})$ were used to assess selenate reduction activity. Reactions in $1 \mathrm{~mL}$ volume were initiated by the addition of $\mathrm{Na}_{2} \mathrm{SeO}_{4}$ to a final concentration of $50 \mathrm{mM}$ at $37^{\circ} \mathrm{C}$ for $0-34 \mathrm{~h}$. Selenate reduction was observed by eye at different times based on the formation of a red-color appearance. 


\section{Purification and Assay of Selenium Nanospheres}

Herbaspirillum sp. WT00C was cultured in LB broth containing $200 \mathrm{mM} \mathrm{Na}_{2} \mathrm{SeO}_{4}$ at $37{ }^{\circ} \mathrm{C}$ for $36 \mathrm{~h}$ and then centrifuged at $800 \times g, 4{ }^{\circ} \mathrm{C}$ to remove bacterial cells. The supernatant was collected and centrifuged again at $6080 \times g, 4{ }^{\circ} \mathrm{C}$ to remove all liquid. The red precipitate was resuspended in PBS ( $\mathrm{pH} 7.2)$ and then centrifuged at $6080 \times g, 4{ }^{\circ} \mathrm{C}$, and this step was repeated three times. Finally, the red precipitate was resuspended in PBS. The Se-nanospheres were further purified by performing a $50-70 \%$ sucrose density gradient centrifugation at $12,000 \times g, 4^{\circ} \mathrm{C}$ for 30 minus as described by Dobias et al. [40]. The red Se-nanosphere band was carefully removed and washed twice with PBS by means of centrifugation at $6080 \times g, 4{ }^{\circ} \mathrm{C}$ for $20 \mathrm{~min}$ to remove all sucrose. The purified Se-nanospheres were then suspended in PBS.

Fehling's reagent was used to test for reducing and nonreducing sugars referring to the Chinese national standard (GB 5513-85), Sudan II [1-(2,4-xylidylazo)-2-naphthol] was used to test the lipoid component, the TLC method [41] was used to test phospholipids, and 10\% SDS-PAGE and Coomassie blue staining were used to test for the presence of proteins in Se-nanospheres.

\section{Bacterial Inoculation and Tea-Cutting Propagation}

Camellia sinensis $\mathrm{cv}$. Chuyeqi was obtained from the Xianning Academy of Agriculture Science and used as parent materials in this study. Tea-cutting propagation was performed according to a conventional approach [31]. In brief, tender shoots of the tea plant in the tea farm were used to prepare tea cuttings with lengths of 5-7 $\mathrm{cm}$. Each cutting carried a single node and a leaf at its upper part. Tea cuttings were planted into seedbeds and cultivated into seedlings.

Two strategies were used for bacterial inoculation. A needle injection method was used to test whether Herbaspirillum sp. WT00C improved selenium enrichment of tea, and tea cuttings were inoculated by soaking to develop a technique for field application. In the needle injection experiment, two-year-old tea seedlings in tea garden were transplanted into pots containing $10 \mathrm{~kg}$ of soil and were cultivated in a greenhouse. Experiments were performed in four groups. The first group was used as control. In the other three groups, $\mathrm{Na}_{2} \mathrm{SeO}_{4}$ was used to spike the soil, and then the selenium contents of soils were assayed. Final selenium contents of soils in four groups were $0,0.622,1.5$, and $3.5 \mathrm{mg} / \mathrm{kg}$. In each group, 100 tea seedlings were cultivated. When tea seedlings sent out young sprouts with 2-3 leaves, equal amounts of bacterial cells $\left(3 \times 10^{10} \mathrm{cfu}\right)$ were injected into the tea stems at $5 \mathrm{~cm}$ above the roots using a sterile needle, after which the wounds were covered by a piece of cotton wool. In the control groups, an equal volume of fresh
LB medium was injected. After injection, all seedlings were continually cultivated in a greenhouse.

Soaking inoculation of tea cuttings was performed based on a method that was reported by our group [31]. In brief, the bacterial culture was prepared as described above, and then glycerol was added to a final concentration of 5\%. After the culture was further diluted with $\mathrm{H}_{2} \mathrm{O}$ (2 bacterial culture: $1 \mathrm{H}_{2} \mathrm{O}$ ), tea cuttings were soaked in the diluted culture for $1 \mathrm{~h}$. In the control group, tea cuttings were soaked in water under the same conditions. After treatment, all tea cuttings were removed from the liquid and dried until no liquid dripping was observed. Next, tea cuttings were immediately planted in a nursery, and field management was performed according to the routine methods used for tea-cutting propagation. After 1 year, tea seedlings were transplanted into pots containing $10 \mathrm{~kg}$ of soil with selenium contents of $0,0.622$, 1.5 , or $3.5 \mathrm{mg} / \mathrm{kg}$ and were cultivated in natural environments. Each of the four groups contained 100 tea seedlings.

\section{Sample Collection and Determination of Selenium Content}

After treatment, 25 tea seedlings in each group were taken out after 30,60, 90, and 150 days and were washed three times with water. The roots, stems, and leaves in each group were separately collected, dehydrated to dryness in a $70{ }^{\circ} \mathrm{C}$ oven, and then ground to a powder. After the powder samples were passed through a 100-mesh screen, the 100-mesh powder of each sample was collected in a sample bag. The selenium content was finally measured using the atomic fluorescence spectrometer (AFS200) according to the National standards of the People's Republic of China (GB/T 21729). Data were collected and analyzed using SPSS24.0, and a $P$ value of less than 0.05 was considered significant.

\section{Results}

\section{Selenate Reduction of Herbaspirillum sp. WT00C}

As reported previously [37], the genomic survey of Herbaspirillum sp. WT00C by means of the analysis technique of bioinformatics resulted in the identification of an intact selenocompound metabolic pathway. In this pathway, selenate is initially converted to selenite, and then selenite is reduced to zerovalent elemental selenium via two intermediates, namely, selenodiglutathione and glutathioselenol, or incorporated into proteins through selenocysteine (see Fig. 1). This bacterium was also found to have an intact pathway for glutathione synthesis. Glutathione was thought to play an important role in selenite reduction [42]. To test if Herbaspirillum sp. WT00C reduces selenate to elemental selenium, it was initially grown at $37{ }^{\circ} \mathrm{C}$ on an LB plate 
containing $25 \mathrm{mM}$ sodium selenate, and all colonies became red in appearance (Fig. 2b). In contrast, the color of bacterial colonies in the control was unchanged (data not shown). Next, Herbaspirillum sp. WT00C was also inoculated into LB broth containing 0 and $200 \mathrm{mM}$ sodium selenate and grown at $37{ }^{\circ} \mathrm{C}$ for $24 \mathrm{~h}$. As shown in Fig. 2c, the medium color became red, whereas the color of the control without sodium selenate did not change. Finally, selenate depletion and selenite formation by Herbaspirillum sp. WT00C were also detected. As shown in Fig. 2d, selenate was gradually depleted when it was incubated in the LB medium containing $1 \mathrm{mg} / \mathrm{mL}$ sodium selenate at $37{ }^{\circ} \mathrm{C}$ for $0-15 \mathrm{~h}$, and selenate residue at $15 \mathrm{~h}$ was approximately $75 \%$. Meanwhile, selenite was gradually increased under the same condition. Red color appetence, selenate depletion, and selenite formation indicated that this bacterium was able to reduce selenate to selenite and then form red elemental selenium $\left(\mathrm{Se}^{0}\right)$.

The growth of Herbaspirillum sp. WT00C in LB broth with different selenate concentrations $(0-200 \mathrm{mM})$ was investigated, and the growth curve is shown in Fig. 2a. When a high concentration $(200 \mathrm{mM})$ of $\mathrm{Na}_{2} \mathrm{SeO}_{4}$ was used, bacterial growth was observably inhibited during 12 -h cultivation. After $12 \mathrm{~h}$, bacterial cells gradually recovered their growth, and finally approached to the wild-type level after $48 \mathrm{~h}$ (see Fig. 2a). This result suggested that this bacterium appears to have a strong selenate tolerance. Viable bacterial count on LB plates showed that bacterial cells were viable when $200 \mathrm{mM}$ selenate was used. The numbers of viable cells observed at $0,12,24$, and $48 \mathrm{~h}$ were $2 \times 10^{6}, 3.3 \times 10^{6}$, $4.2 \times 10^{8}$, and $1.4 \times 10^{11} \mathrm{cfu} / \mathrm{mL}$, respectively, demonstrating that bacterial cells kept alive during 12-h incubation and recovered their growth after a 12-h inhibition.

Herbaspirillum sp. WT00C was grown in LB broth containing $200 \mathrm{mM} \mathrm{Na}_{2} \mathrm{SeO}_{4}$ at $37{ }^{\circ} \mathrm{C}$ for $0-24 \mathrm{~h}$, and culture samples were taken at $5,7,10,15,20$, and $24 \mathrm{~h}$ and observed by transmission electron microscopy (TEM). TEM revealed that Herbaspirillum sp. WT00C reduced selenate $\left(\mathrm{Se}^{6+}\right)$ to elemental selenium $\left(\mathrm{Se}^{0}\right)$ nanoparticles (SeNPs), which ranged in size from a few nanometers to more than $200 \mathrm{~nm}$ (Fig. 3). As shown in Fig. 3, SeNPs were spherical in shape and gradually increased in size as the bacterial incubation time increased. Selenium nanoparticles initially gathered together to form selenium nanospheres outside bacterial cells (Fig. 3a, b) and then grew larger through fusion between small Se-nanospheres (Fig. 3d, e), and finally crystallized to form selenium flowers with diameters of more than $1 \mu \mathrm{m}$ (Fig. 3f, g). The results from scanning electron microscopy (SEM) observation gave more detailed information regarding bacterial cells and SeNPs. As shown in Fig. $3 \mathrm{~h}-\mathrm{j}$, bacterial cells were intact, and SeNPs initially assembled onto cell surfaces as dispersed shapes and then formed Se-nanospheres outside bacterial cells. The SeNPs scattered as a dispersed shape on the cell surfaces suggested that they could be secreted from the bacterial cytoplasm to the exterior of cells, where Se-nanospheres were subsequently formed.

To further confirm whether Herbaspirillum sp. WT00C reduced selenate to elemental selenium $\left(\mathrm{Se}^{0}\right)$, a bacterial culture sample at $24 \mathrm{~h}$ described above was analyzed using energy-dispersive X-ray spectroscopy (EDS). As shown in Fig. 4, the Se-nanospheres gathered together in the box showed a strong blue spectrum of selenium (Fig. 4b) and a typical peak for the electromagnetic emission spectrum of selenium (Fig. 4c). X-ray diffraction (XRD) patterns also showed that this mixture containing bacterial cells and the extracellular red SeNPs had four intense peaks over the whole spectrum of the 2 values ranging from 5 to 90 . These intense peaks matched perfectly with the standard spectrum
Fig. 1 The pathway of selenocompound metabolism in Herbaspirillum sp. WT00C

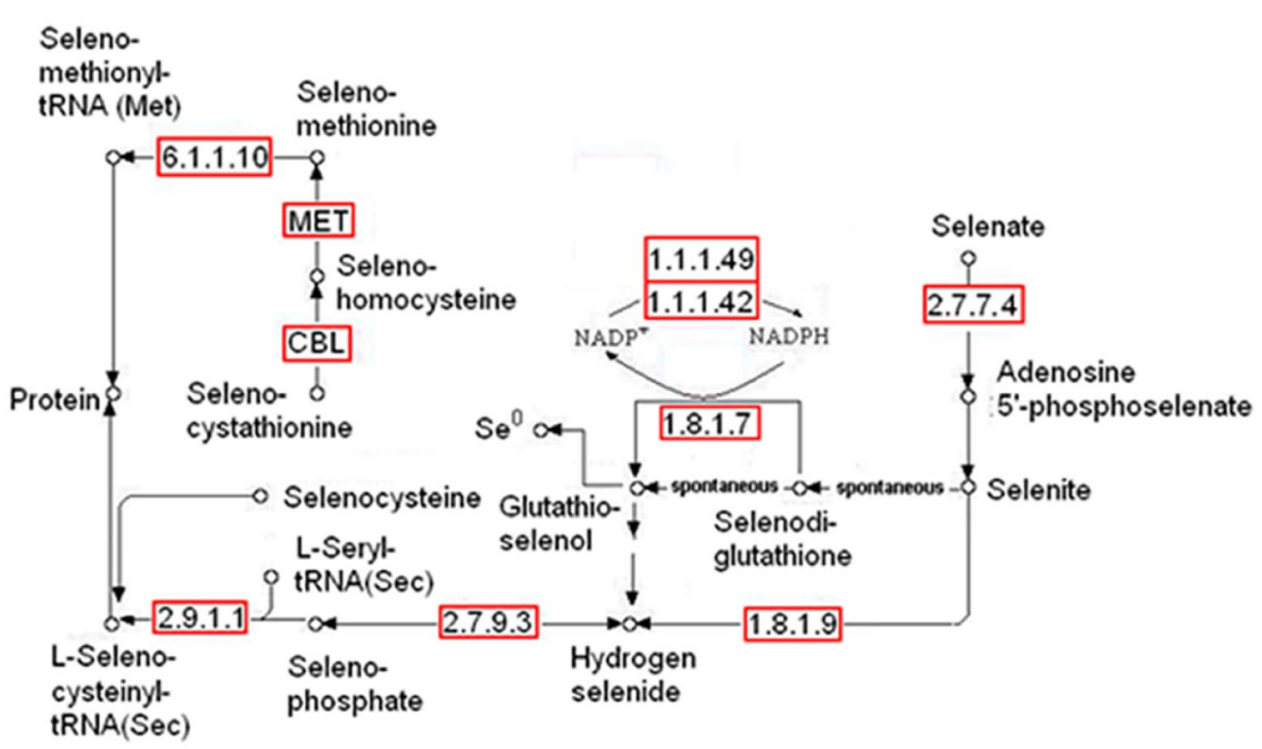


Fig. 2 Growth inhibition and selenate reduction of Herbaspirillum sp. WT00C. a Growth curves of Herbaspirillum sp. WT00C in LB broth with different selenate concentrations (0-200 mM); b Colonies of Herbaspirillum sp. WT00C growing at $37^{\circ} \mathrm{C}$ on the LB plate containing $25 \mathrm{mM}$ selenate; c Selenate reduction by Herbaspirillum sp. WT00C in $200 \mathrm{~mL}$ LB medium containing 0 or $200 \mathrm{mM} \mathrm{Na}_{2} \mathrm{SeO}_{4}$ at $37{ }^{\circ} \mathrm{C}$ for $24 \mathrm{~h}$; d Selenate depletion and selenite formation curves of Herbaspirillum sp. WT00C incubating in the LB medium containing $1 \mathrm{mg} /$ for $0-15 \mathrm{~h}$ $\mathrm{mL}$ sodium selenate at $37^{\circ} \mathrm{C}$

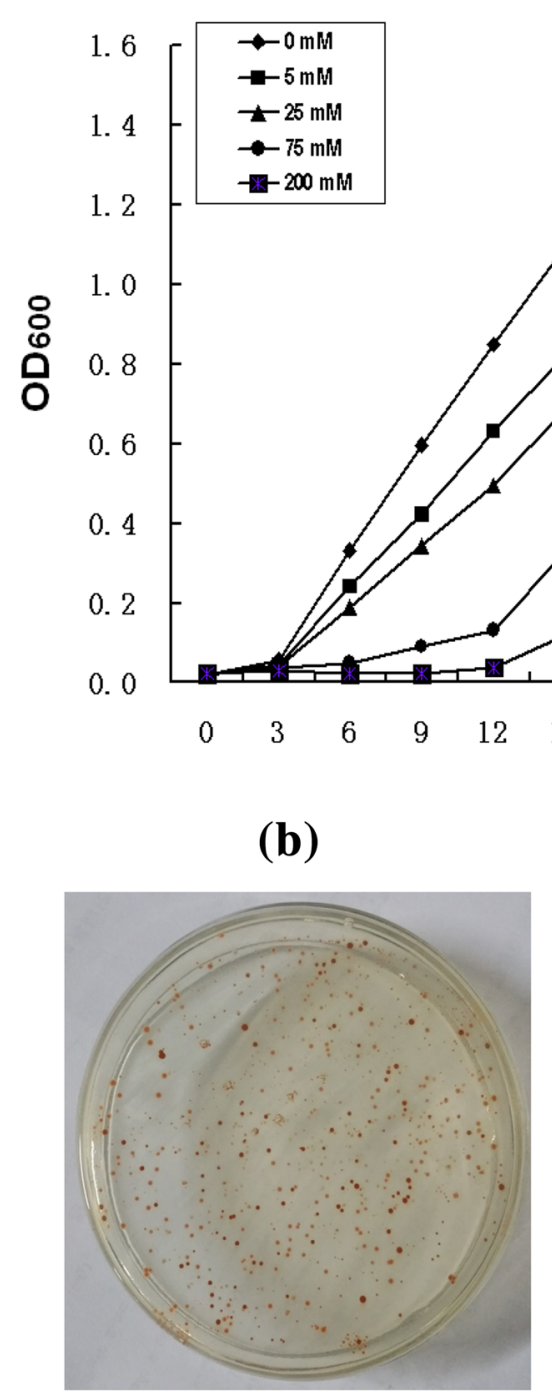

(a)

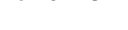


(a)
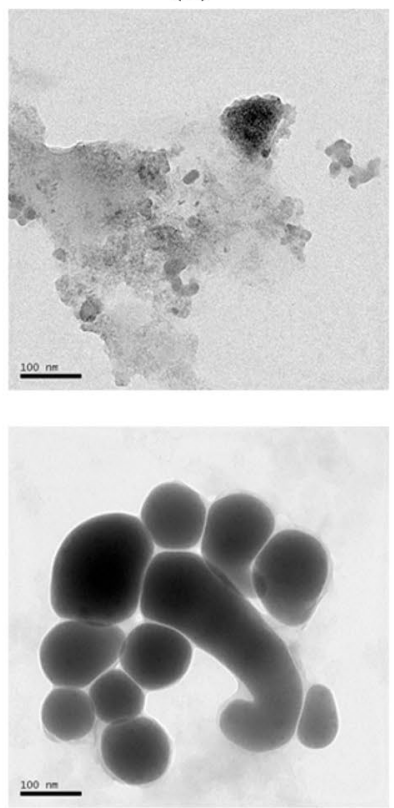

(d) (b)
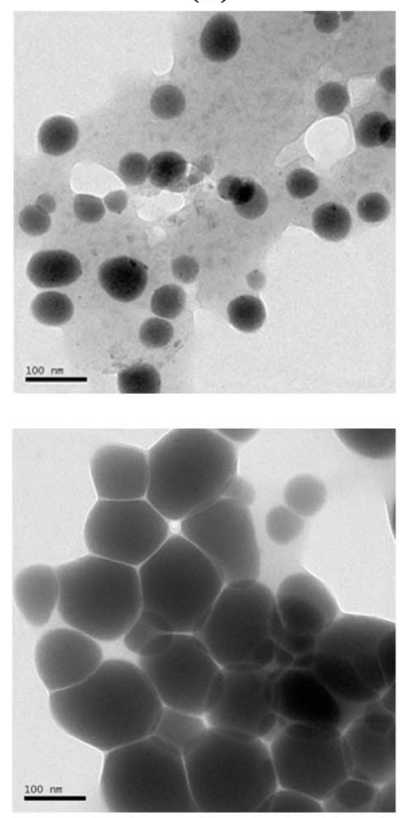

(e) (c)
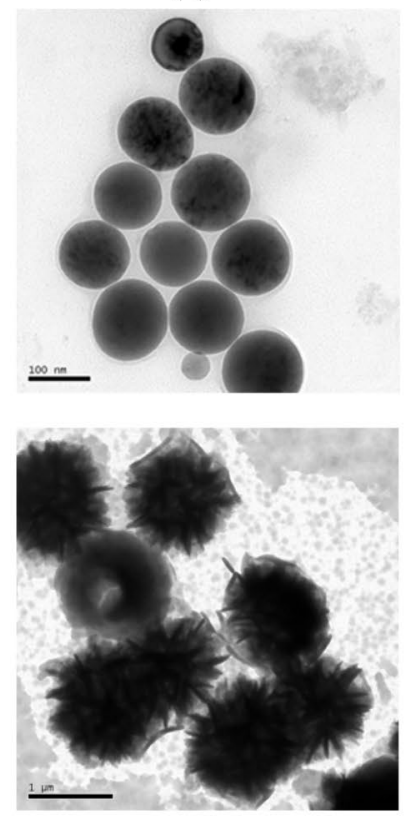

(f)

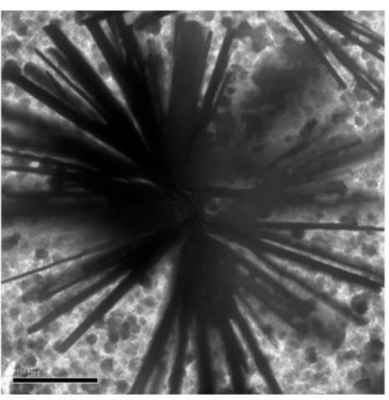

(g)

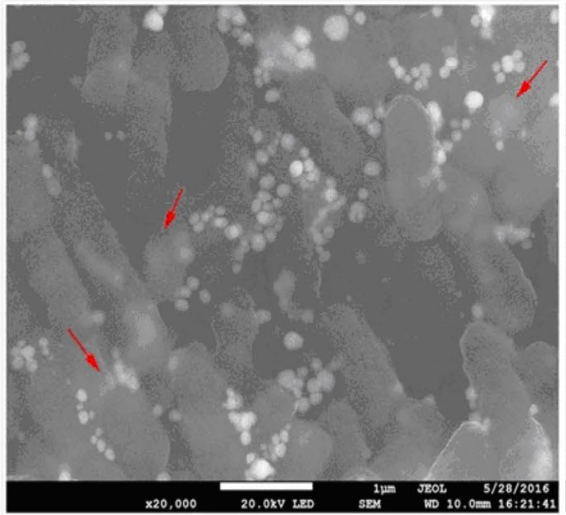

(h)

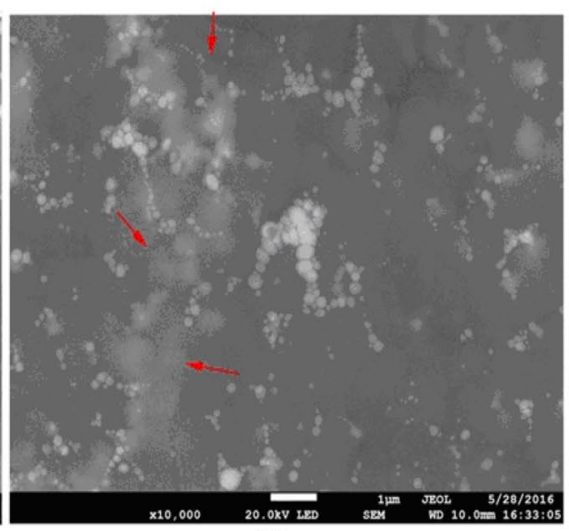

(i)

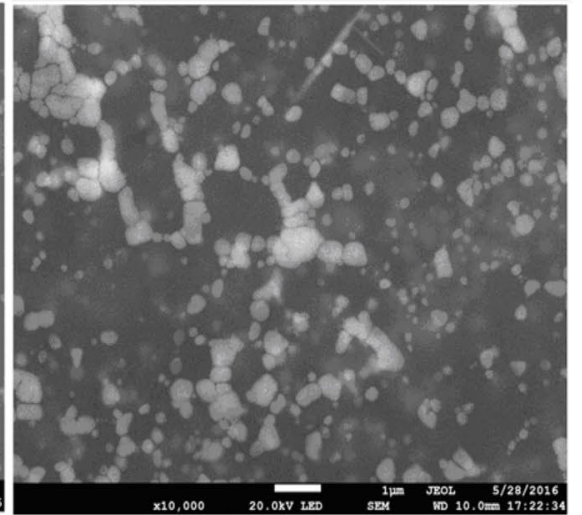

(j)
Fig. 3 TEM and SEM observations of selenium nanoparticles. $\mathbf{a}-\mathbf{g}$ TEM observations of selenium nanoparticles at 5, 7, 10,15, 20, and $24 \mathrm{~h}$ of bacterial culturing at $37{ }^{\circ} \mathrm{C}$ with $200 \mathrm{mM} \mathrm{NaSeO}$. h-j SEM observations of bacterial cells and selenium nanoparticles at 12, 24,

of elemental selenium $\left(\mathrm{Se}^{0}\right)$; obtained from the database of the National Research Council of Canada Crystallographic Data File, NRCC) but did not match with the standard spectrum of $\mathrm{Se}^{6+}$ (data not shown). These results clearly confirmed that Herbaspirillum sp. WT00C reduced selenate $\left(\mathrm{Se}^{6+}\right)$ to elemental selenium $\left(\mathrm{Se}^{0}\right)$.

To test the selenate reduction activities of cytoplasmic proteins and cell debris, $50 \mathrm{mM} \mathrm{Na}{ }_{2} \mathrm{SeO}_{4}$ was added to $0.3 \mathrm{mg} / \mathrm{mL}$ proteins, and the selenate reduction activity was observed at different times. As shown in Fig. 5b, cytoplasmic proteins displayed a red color after $24 \mathrm{~h}$, and the proteins from cell debris produced a red color after $34 \mathrm{~h}$ under and $48 \mathrm{~h}$ of bacterial culturing with $200 \mathrm{mM} \mathrm{NaSeO}_{4}$ at $37^{\circ} \mathrm{C}$. SeNPs scattered as dispersed shapes on cell surfaces were indicated by a red arrowhead

the same conditions, indicating that the activity of selenate reduction of cytoplasmic proteins was more active than that of bacterial membranes. This observation suggested that the reaction of selenate reduction occurs inside and outside bacterial cells but predominantly occurs inside cells.

Se-nanospheres were purified from bacterial cultures and tested with Fehling's reagent, but both reducing and nonreducing sugars were undetectable. The Sudan II test also gave negative result, suggesting that Se-nanospheres did not contain lipoid. In addition, the results of a TLC analysis did not identify any phospholipids in Se-nanospheres. In contrast, a 10\% SDS-PAGE gel showed that 
Fig. 4 EDS and XRD analyses of spectrum patterns. a SEM observation of bacterial cells and Se-nanospheres; $\mathbf{b}$ Se-nanospheres displayed a strong blue selenium spectrum; c Electromagnetic emission spectra of chemical elements of bacterial cells and SeNPs in which selenium occurred as a large peak; $\mathbf{d}$ XRD spectral patterns of bacterial cells and SeNPs, which matched perfectly with the standard spectrum of elemental selenium $\left(\mathrm{Se}^{0}\right)$ (a)

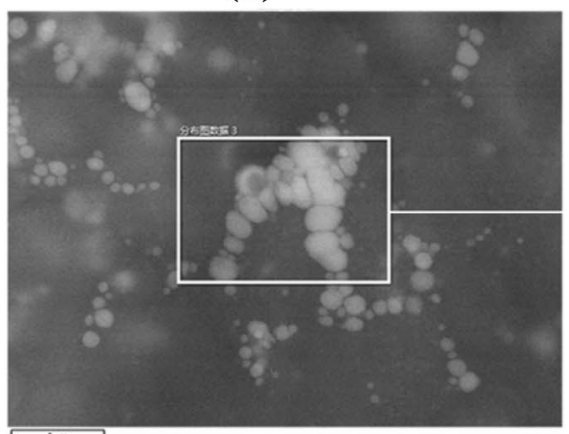

(b)
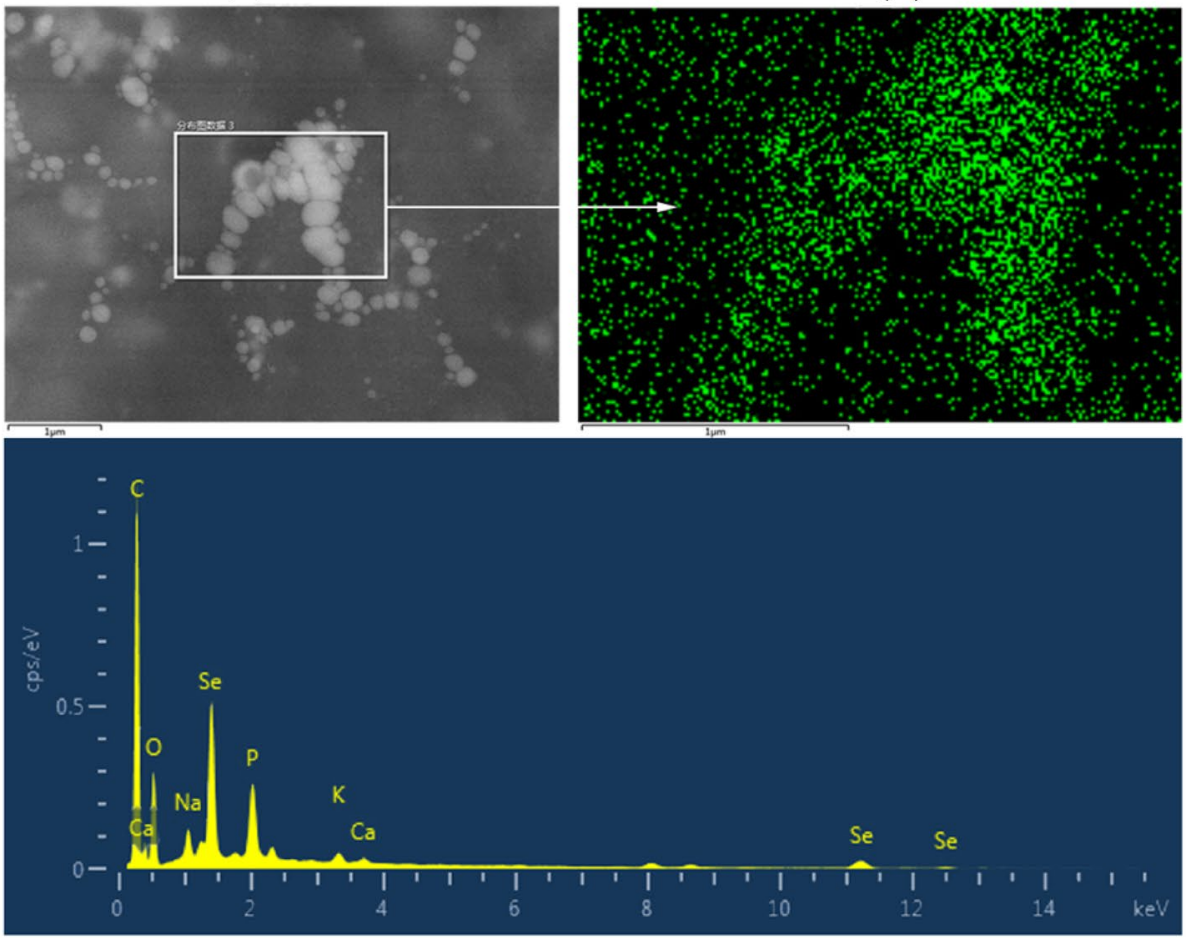

(c)

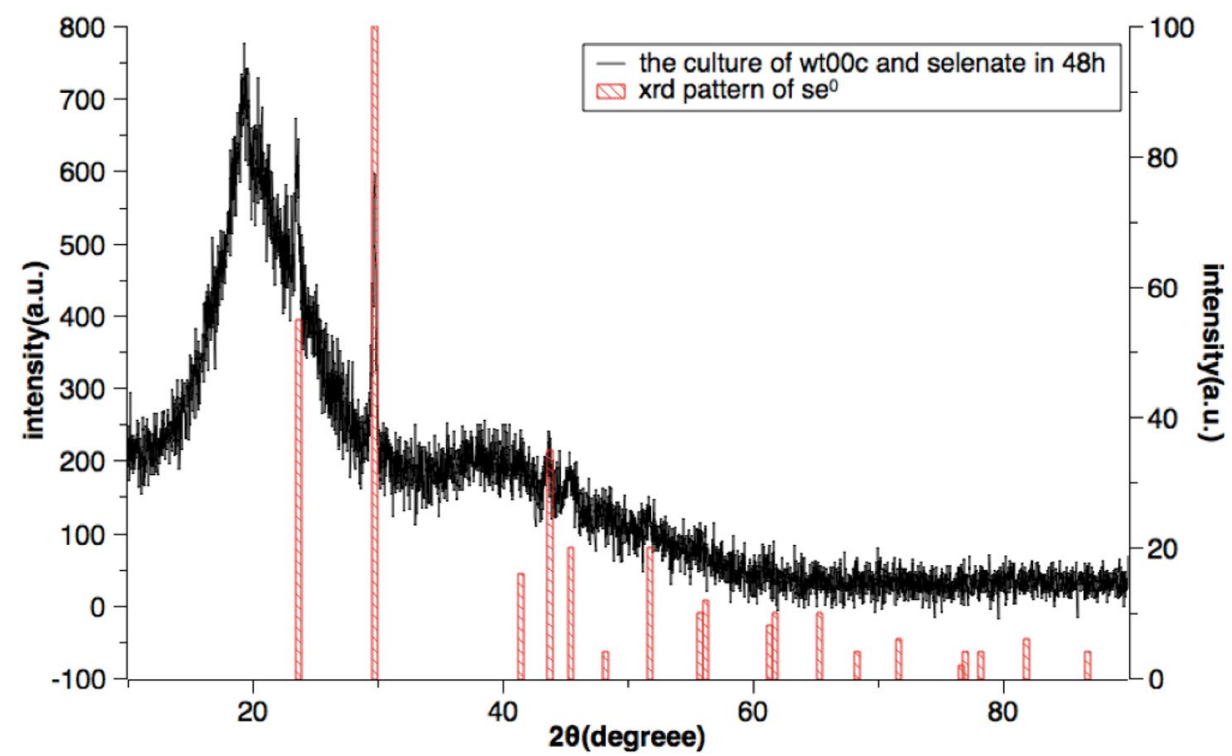

(d)
Se-nanospheres contained proteins, which exhibited four major protein bands with molecular weights of 92,56 , 37 , and $23 \mathrm{kDa}$ (see Fig. 5). These results indicated that Se-nanospheres contain proteins but not carbohydrates or lipids. As shown in Fig. 5, the proteins of Se-nanospheres appeared to come from bacterial cells.

\section{Improvement of Selenium Enrichment of Tea by Herbaspirillum sp. WTOOC}

Herbaspirillum sp. WT00C is a gram-negative, tea-specific endophytic bacterium $[30,31]$ that enters tea plants via traumatic infection and primarily colonizes inside stems or old leaves of tea plants [33]. Because of its ability to reduce selenate to form protein-containing Se-nanospheres, this 


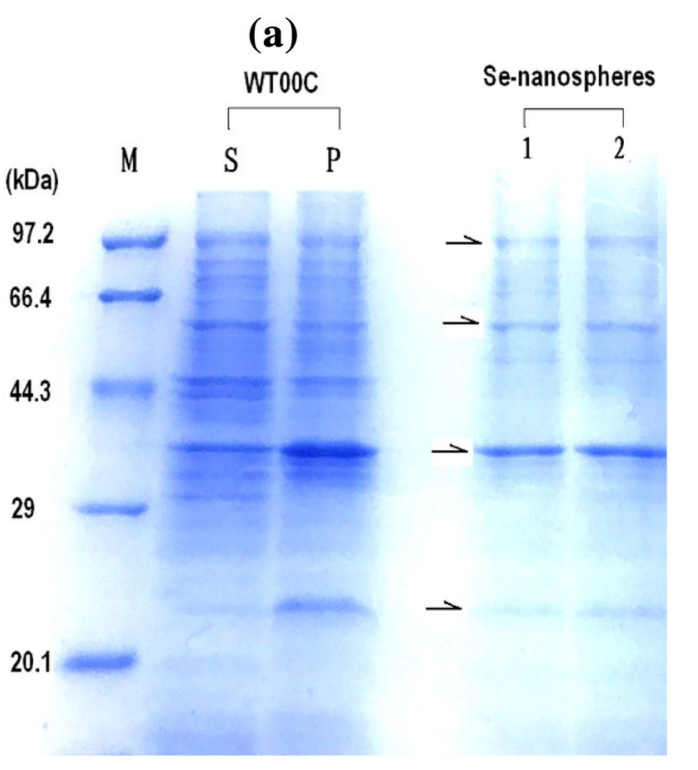

Fig. 5 Protein assay of Se-nanospheres and activity test of selenate reduction of cytoplasmic and cell-debris proteins. a Protein assay of Se-nanospheres by $10 \%$ SDS-PAGE. The primary protein band is indicated by pointed by an arrow. WT00C: Herbaspirillum sp. WT00C; S: supernatant; P: pellet; M: protein marker. b Selenate

bacterium might improve selenium enrichment of tea when it colonizes tea plants growing in selenate-containing soils. To test this possibility, we designed two methods, needle injection and soaking tea cuttings, to inoculate Herbaspirillum sp. WT00C into tea plants. The two methods were assessed because the needle injection method is only used for laboratory test but is not applicable for use in tea fields, whereas the soaking tea cutting method can be used in tea fields.

In the needle injection experiment, we inoculated the bacterium by needle injection into the stems of tea seedlings growing in soil with different selenate concentrations $(0.622$, 1.5 and $3.5 \mathrm{mg} / \mathrm{kg}$ ). After 30, 60, 90, and 180 days post injection, the roots, stems, and leaves of tea seedlings were collected, and selenium contents were measured. As shown in Fig. 6a-c, the selenium contents of the roots, stems, and leaves increased along with the increasing selenate concentration in soil, indicating that tea plants were able to become enriched for selenium to a certain extent. Nevertheless, the selenium distribution in the roots, stems, and leaves of tea plants in the control groups did not show obvious difference. Different from the control groups, all three experimental groups showed a marked selenium enrichment in tea leaves. After tea plants were inoculated with Herbaspirillum sp. WT00C, the selenium contents of tea leaves were approximately twice that as those for the control groups. A significant difference $(P<0.01)$ in the selenium contents of tea leaves between the control and experimental groups illustrated that the colonization of Herbaspirillum sp. WT00C (b)

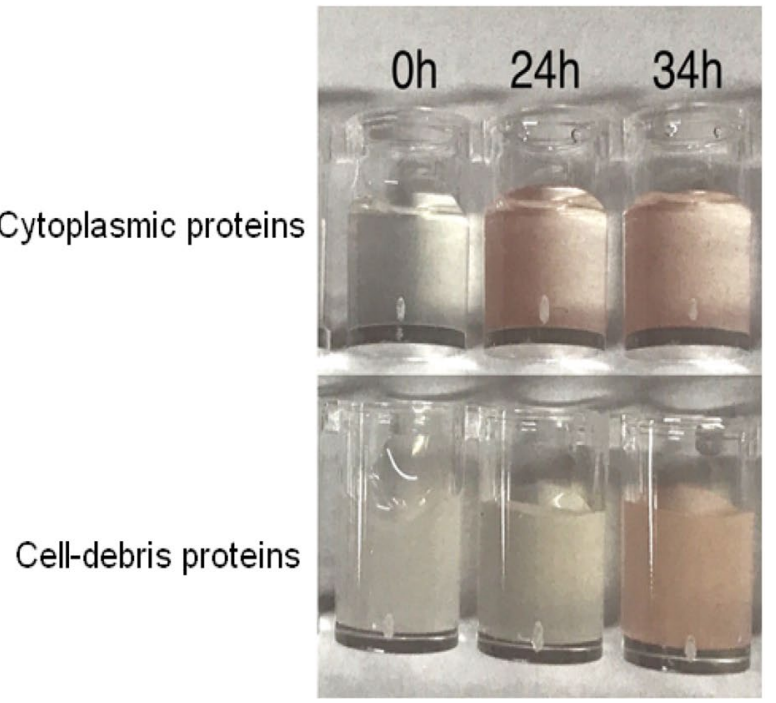

reduction activities of cytoplasmic and cell-debris proteins. In both cases, $50 \mathrm{mM} \mathrm{Na}_{2} \mathrm{SeO}_{4}$ and $0.3 \mathrm{mg} / \mathrm{mL}$ protein were mixed in $50 \mathrm{mM}$ phosphate buffer ( $\mathrm{pH}$ 7.2) and then incubated at $37{ }^{\circ} \mathrm{C}$ for different times

inside tea plants strongly enhanced selenium enrichment in tea leaves. Non-selenium soil was also used to cultivate tea seedlings with or without inoculation of Herbaspirillum $\mathrm{sp}$. WT00C, and the selenium contents in the roots, stems, and leaves of these plants was examined. In both cases, the selenium content was quite low $(<0.2 \mathrm{mg} / \mathrm{kg})$ in the roots, stems or leaves (data not shown). Thus, selenium enrichment in tea plants depended on a selenium source in the soil, and improving selenium enrichment of tea by Herbaspirillum sp. WT00C only occurred when tea plants grew in those selenium-containing soils.

In the soaking tea-cutting method, we introduced the bacterium into tea seedlings by means of tea-cutting propagation. When tea cuttings were soaked in the bacterial culture, Herbaspirillum sp. WT00C entered tea cuttings via incisions at the lower end of each tea cutting. The tea-cutting seedlings with Herbaspirillum sp. WT00C were then transplanted into soils containing different concentrations of selenate as described above. Tea-cutting seedlings without bacterial inoculation were grown under the same conditions and used as a control. Figure $6 \mathrm{~d}-\mathrm{f}$ shows the observed selenium contents of roots, stems, and leaves of tea seedlings at different times post-transplantation. Similar to the results shown in Fig. 6a-c, the selenium contents in the roots or stems of the control and experimental groups were almost comparable. In contrast, the selenium contents in tea leaves were significantly different $(P<0.01)$. In all three treatments, the selenium contents of tea leaves in the experimental groups were more than twofold higher than that observed in the control 

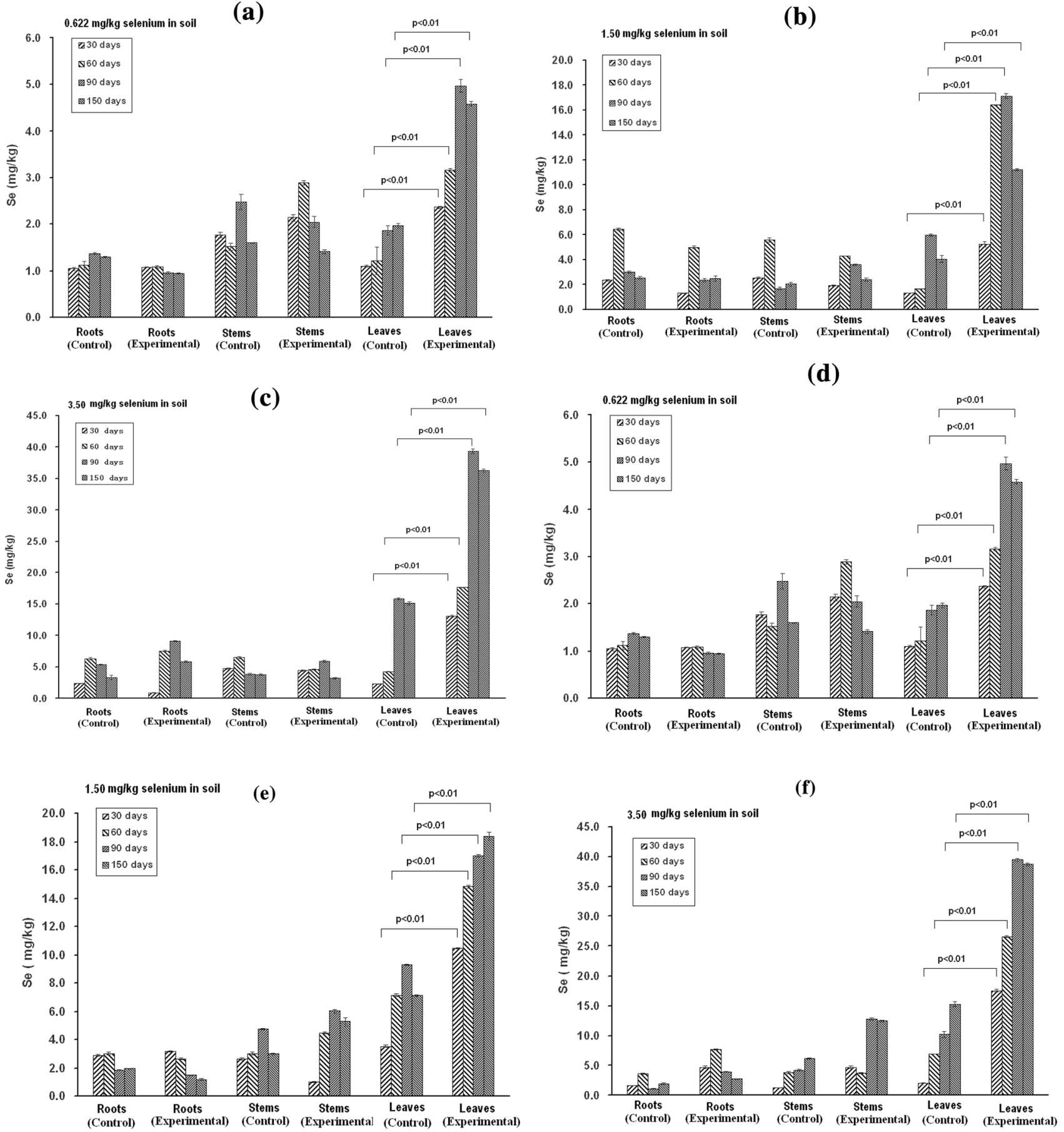

Fig. 6 Selenium contents of roots, stems, and leaves of tea seedlings. The data were collected at 30,60, 90, and 150 days posttreatment. a-c Bacterial inoculation by a needle injection method and $\mathbf{d}-\mathbf{f}$ Bacterial inoculation by soaking tea-cutting method. a, $\mathbf{d}$ The data were obtained from the tea seedlings growing in soil with $0.622 \mathrm{mg} / \mathrm{kg}$

groups. Thus, the marked selenium enrichment in tea leaves demonstrated that Herbaspirillum sp. WT00C had the ability to enhance selenium enrichment of tea after it colonized in tea plants.

selenium; b, e The data were obtained from tea seedlings growing in soil with $1.5 \mathrm{mg} / \mathrm{kg}$ selenium; and $\mathbf{c}, \mathbf{f}$ The data were obtained from tea seedlings growing in soil with $3.5 \mathrm{mg} / \mathrm{kg}$ selenium. Significant difference was marked for selenium contents of tea leaves between the control and experimental groups

\section{Discussion}

A genomic survey [37] found that Herbaspirillum sp. WT00C, similar to Herbaspirillum sp. Os34 and other 
bacteria [43-45], possesses an intact pathway for selenocompound metabolism, where selenate is initially converted to selenite and is then further reduced to zerovalent elemental selenium or incorporated into proteins through selenocysteine. After incubation of the bacterial cells with sodium selenate, Herbaspirillum sp. WT00C indeed turned the medium red and depleted selenate. Furthermore, SEM, TEM, and XRD analyses confirmed that Herbaspirillum sp. WT00C had the ability to reduce selenate to red elemental selenium. Although a high concentration of selenate initially inhibited its growth, the bacterium recovered its ability to grow when the selenate in the medium fell to a low concentration. In view of the fact that Herbaspirillum sp. WT00C was able to survive in more than $200 \mathrm{mM}$ selenate, this bacterium obviously had a strong capacity of selenate tolerance. Nevertheless, the detailed mechanism needs to be studied still further. In selenate reduction experiments, the cytoplasmic extract was more active than the cell-debris precipitate, suggesting that the selenate reduction primarily occurred inside bacterial cells. After selenate was reduced to elemental selenium, the elemental selenium further formed SeNPs inside bacterial cells. Those SeNPs, associated with bacterial proteins, were secreted to bacterial surfaces in the shape of selenium granules and then aggregated to form small Se-nanospheres. Small Se-nanospheres grew larger outside bacterial cells via fusion between Se-nanospheres. Finally, elemental selenium in large nanospheres further crystallized to form selenoflowers (Fig. 3). In this bacterium, selenate reduction primarily occurred inside the bacterial cell, and then Se-nanospheres grew and accumulated outside the bacterial cell, similar to reports in Bacillus mycoides SeITE01 [46] and Bacillus cereus [42] under aerobic conditions but different from those reported in Shewanella oneidensis MR-1 [47] Rhodospirillum rubrum and E. coli [45].

Based on its selenium reduction and metabolic capacity, as well as endophytic host specificity, we hypothesized that Herbaspirillum sp. WT00C might improve selenium enrichment of tea when the bacterium colonized inside tea plants. Our results, obtained from both needle injection and soaking tea-cutting methods, demonstrated that endophytic Herbaspirillum sp. WT00C indeed enhanced selenium enrichment in tea leaves. Here, it is inevitable to raise a question how Herbaspirillum sp. WT00C improves the selenium enrichment of tea. When tea plants grow in the selenium-containing soil, selenate or selenite enters tea plants via root absorption and then reaches to the upper part of tea plants through plant vessel transportation. Inside plant cells, selenate/selenite is metabolized to selenium compounds [1,3]. Selenate $\left(\mathrm{SeO}_{4}{ }^{2-}\right)$ and selenite $\left(\mathrm{SeO}_{3}{ }^{2-}\right.$ ), two oxidized forms (oxyanions) of selenium, usually exist in natural environments, and both compounds are soluble in water but toxic to living things [2]. Elemental selenium $\left(\mathrm{Se}^{0}\right)$ is insoluble but exhibits no or very little toxicity [1, 13]. As it predominantly colonizes inside the stem of tea plants [31], Herbaspirillum sp. WT00C present in tea plant stems can reduce selenate and selenite to produce elemental selenium, selenodiglutathione, glutathioselenol, selenocysteine, selenomethionine, or selenoproteins when inorganic selenocompounds are absorbed via roots and transported into the stems of tea plants through the conducting system of tea-plant xylem. The selenate reduction of Herbaspirillum sp. WT00C
Fig. 7 A plausible mechanism for the enhancement of selenium enrichment by Herbaspirillum sp. WT00C

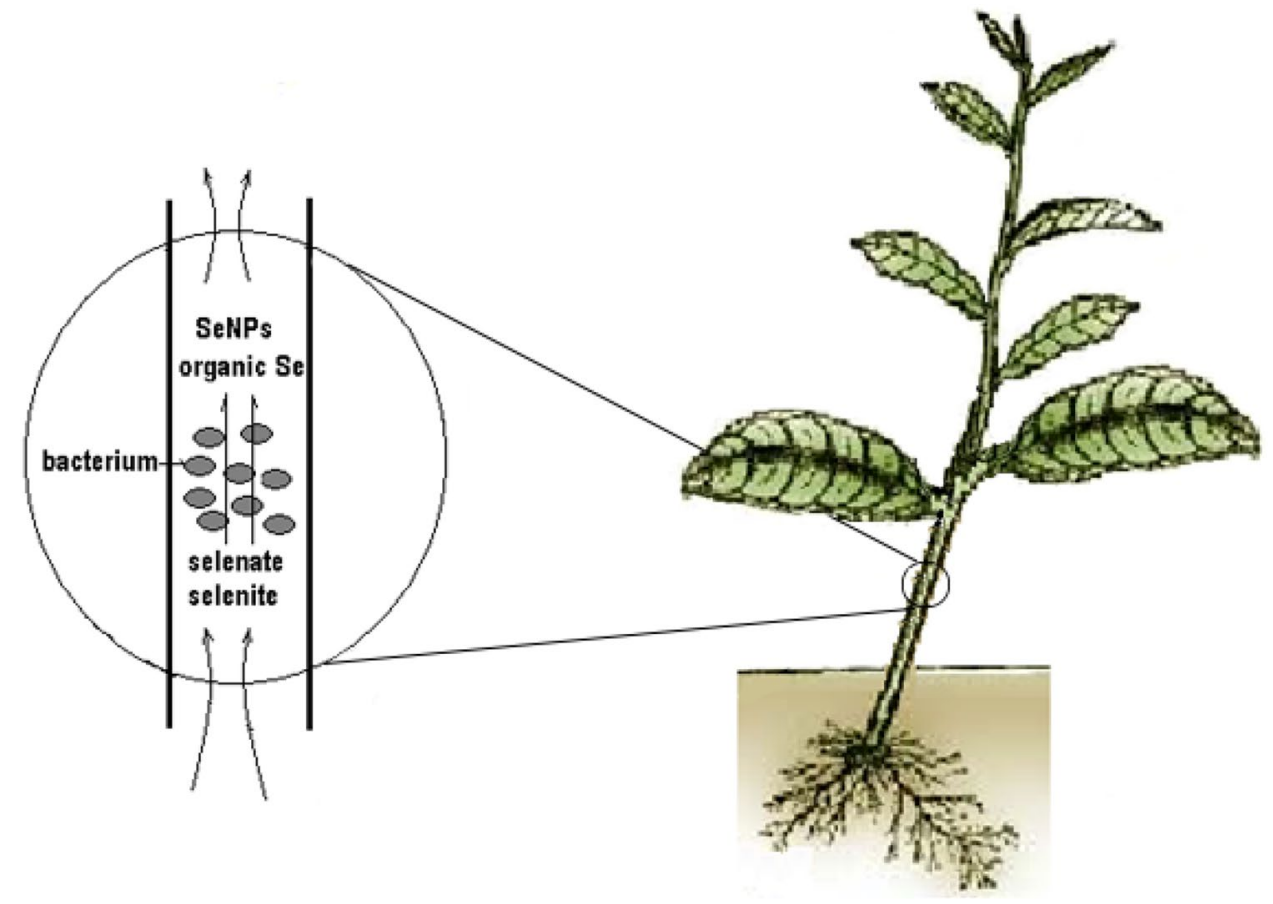


not only decreases the toxicity of inorganic selenocompounds absorbed by plant roots to maintain vigorous growth of tea plants but also forms organic selenium and Se-nanoparticles. Organic selenocompounds can be directly accumulated and utilized by tea-plant cells, whereas atoxic Se-nanoparticles associated with proteins can be transported to tea leaves by means of plant transpiration, where Se-nanoparticles may be further metabolized to form organic selenium in tea-plant cells or be directly taken into the tissues of tea leaves (Fig. 7).

Selenium contents vary from 0.5 to $3.5 \mathrm{mg} / \mathrm{kg}$ in agricultural soil of selenium-rich areas [48]. In our study, soils containing $0.622,1.5$, and $3.5 \mathrm{mg} / \mathrm{kg}$ inorganic selenium were used for the cultivation of tea plants. When the soaking teacutting method was used, the selenium contents in tea leaves were 5,18 , and $40 \mathrm{mg} / \mathrm{kg}$, respectively, two times more than those observed in the control groups. The higher selenium content observed in tea leaves demonstrates that selenium enrichment of tea is indeed improved by Herbaspirillum sp. WT00C. Our studies not only show the capability of Herbaspirillum sp. WT00C to improve selenium enrichment of tea but also offer a novel technique for field application by tea farmers.

Acknowledgements This work was supported by a grant (Grant Number 2016YFD0200905) from the Ministry of Science and Technology of the People's Republic of China, and also assisted by an innovationdriven power program of the Hubei Association for Science and Technology, Hubei province, China.

Open Access This article is distributed under the terms of the Creative Commons Attribution 4.0 International License (http://creativeco mmons.org/licenses/by/4.0/), which permits unrestricted use, distribution, and reproduction in any medium, provided you give appropriate credit to the original author(s) and the source, provide a link to the Creative Commons license, and indicate if changes were made.

\section{References}

1. Hartikainen H, Xue T, Piironen V (2000) Selenium as an antioxidant and pro-oxidant in ryegrass. Plant Soil 225:193-200

2. Lyons GH, Genc Y, Soole K, Stangoulis JCR, Liu F, Graham RD (2009) Selenium increases seed production in Brassica. Plant Soil 318:73-80

3. Turakainen M, Hartikainen H, Seppanen MM (2004) Effects of selenium treatments on potato (Solanum tuberosum L.) growth and concentrations of soluble sugars and starch. J Agric Food Chem 52:5378-5382

4. Cox DN, Bastiaans K (2007) Understanding Australian consumers' perceptions of selenium and motivations to consume selenium enriched foods. Food Qual Prefer 18:66-76

5. Tapiero H, Townsend DM, Tew KD (2003) The antioxidant role of selenium and seleno-compounds. Biomed Pharmacother $57: 134-144$

6. Ip C, Thompson HJ, Zhu Z, Ganther HE (2000) In vitro and in vivo studies of methylseleninic acid: evidence that a monomethylated selenium metabolite is critical for cancer chemoprevention. Cancer Res 60:2882-2886

7. Miller S, Walker SW, Arthur JR, Nicol F, Pickard K, Lewin MH, Howie AF, Beckett GJ (2001) Selenite protects human endothelial cells from oxidative damage and induces thioredoxin reductase. Clin Sci 100:543-550

8. Hunter WJ, Kuykendall LD, Manter DK (2007) Rhizobium selenireducens $\mathrm{sp}$. nov.: a selenite-reducing $\alpha$-proteobacteria isolated from a bioreactor. Curr Microbiol 55:455-460

9. Klonowska A, Heulin T, Vermeglio A (2005) Selenite and tellurite reduction by Shewanella oneidensis. Appl Environ Microbiol 71:5607-5609

10. Morita M, Uemoto H, Watanabe A (2007) Reduction of selenium oxyanions in wastewater using two bacterial strains. Eng Life Sci 7:235-240

11. Rathgeber C, Yurkova N, Stackebrandt E, Beatty JT, Yurkov $\mathrm{V}$ (2002) Isolation of tellurite- and selenite-resistant bacteria from hydrothermal vents of the juan de fuca ridge in the pacific ocean. Appl Environ Microbiol 68:4613-4622

12. Tam K, Ho CT, Lee JH, Lai M, Chang CH, Rheem Y, Chen W, Hur HG (2010) Growth mechanism of amorphous selenium nanoparticles synthesized by Shewanella sp. HN-41. Biosci Biotech Biochem 74:696-700

13. Wadhwani SA, Shedbalkar UU, Singh R, Chopade BA (2016) Biogenic selenium nanoparticles: current status and future prospects. Appl Microbiol Biotechnol 100:2555-2566

14. Husen A, Siddiqi KS (2014) Plants and microbes assisted selenium nanoparticles: characterization and application. J Nanobiotechnol 12:28

15. Lortie L, Gould WD, Rajan S, McCready RG, Cheng KJ (1992) Reduction of selenate and selenite to elemental selenium by a Pseudomonas stutzeri isolate. Appl Environ Microbiol 58:4042-4044

16. Narasingarao P, Haggblom MM (2007) Identification of anaerobic selenaterespiring bacteria from aquatic sediments. Appl Environ Microbiol 73:3519-3527

17. Oremland RS, Blum JS, Culbertson CW, Visscher PT, Miller LG, Dowdle P, Strohmaier FE (1994) Isolation, growth, and metabolism of an obligately anaerobic, selenaterespiring bacterium, strain SES-3. Appl Environ Microbiol 60:3011-3019

18. Sabaty M, Avazeri C, Pignol D, Vermeglio A (2001) Characterization of the reduction of selenate and tellurite by nitrate reductases. Appl Environ Microbiol 67:5122-5126

19. Hunter WJ, Kuykendall LD, Manter DK (2009) Rhizobium selenireducens sp. nov.: a selenite-reducing $\alpha$-proteobacteria isolated from a bioreactor. Curr Microbiol 55:455-460

20. Mukhtar H, Ahmad N (2000) Tea polyphenols: prevention of cancer and optimizing health. Am J Clin Nutr 71(suppl):1698S-1702S

21. Dreosti IE, Wargovich MJ, Yang CS (1997) Inhibition of carcinogenesis by tea: the evidence from experimental studies. Crit Rev Food Sci Nutr 37:761-770

22. Katiyar SK, Mukhtar H (1996) Tea in chemoprevention of cancer: epidemiologic and experimental studies. Int J Oncol 8:221-238

23. Kohlmeier L, Weterings KGC, Steck S, Kok FJ (1997) Tea and cancer prevention: an evaluation of the epidemiologic literature. Nutr Cancer 27:1-13

24. Sadzuka Y, Sugiyama T, Hirota S (1998) Modulation of cancer chemotherapy by green tea. Clin Cancer Res 4:153-156

25. Weisburger JH, Rivenson A, Garr K, Aliaga C (1997) Tea, or tea and milk, inhibit mammary gland and colon carcinogenesis in rats. Cancer Lett 114:323-327

26. Stensvold I, Tverdal A, Solvoll K, Foss OP (1992) Tea consumption: relationship to cholesterol, blood pressure, and coronary and total mortality. Prev Med 21:546-553

27. Thelle DS (1995) Coffee, tea and coronary heart disease. Curr Opin Lipidol 6:25-27

28. Tijburg LBM, Wiseman SA, Meijer GW, Weststrate JA (1997) Effects of green tea, black tea and dietary lipophilic antioxidants 
on LDL oxidizability and atherosclerosis in hypercholesterolaemic rabbits. Atherosclerosis 135:37-48

29. Benstoem C, Goetzenich A, Kraemer S, Borosch S, Manzanares W, Hardy G, Stoppe C (2015) Selenium and its supplementation in cardiovascular disease-what do we know? Nutrients 7:3094-3118

30. Wang T, Yang S, Chen Y, Hu L, Tu Q, Zhang L, Liu X, Wang $X$ (2014) Microbiological properties of two endophytic bacteria isolated from tea (Camellia sinensis L.). Acta Microbiol Sin 54(4):424-432

31. Zhan G, Cheng W, Liu W, Li Y, Ding K, Rao H, Wu W, Wang $\mathrm{W}$ (2016) Infection, colonization and growth-promoting effects of tea plant (Camellia sinensis L.) by the endophytic bacterium Herbaspirillum sp. WT00C. Afr J Agric Res 11(3):130-138

32. Baldani JI, Baldani VLD, Seldin LD, Bereiner J (1986) Characterization of Herbaspirillum seropedicae gen. nov, sp. Nov., a root-associated nitrogen-fixing bacterium. IJSB 36(1):86-93

33. Kirchhof G, Eckert B, Stoffels M, Baldani JI, Reis VM, Hartmann A (2001) Herbaspirillum rubrisubalbicans sp. Nov., a new nitrogen-fixing bacterial species that occurs in C4-fibre plants. IJSB 51(1):157-168

34. Valverde A, Velazquez E, Gutierrez C, Cervantes E, Ventosa A, Igual JM (2003) Herbaspirillum lusitanum sp. Nov., a novel nitrogen-fixing bacterium associated with root nodules of Phaseolus vulgaris. IJSB 53(6):1979-1983

35. McSteen P (2010) Auxin and monocot development. Cold Spring Harb Perspect Biol 2:1-27

36. Neilands JB (1995) Siderophores: structure and function of microbial iron transport compounds. JBC 270(45):26723-26726

37. Cheng W, Zhan G, Liu W, Zhu R, Yu X, Li Y, Li Y, Wu W, Wang X (2017) Draft genome sequence of endophytic Herbaspirillum sp. strain WT00C, a tea plant growth-promoting bacterium. Genome Announc. 5:e01719. https://doi.org/10.1128/genom eA.01719-16

38. Li B, Liu N, Li Y, Jing W, Fan J, Li D, Zhang L, Zhang Z, Wang L (2014) Reduction of selenite to red elemental selenium by Rhodopseudomonas palustris strain N. PLoS ONE 9(4):e95955. https ://doi.org/10.1371/journal.pone.0095955

39. Bradford M (1976) A rapid and sensitive method for the qualification of microgram quantities of protein utilizing the principle of protein-dye binding. Anal Biochem 72:248-254
40. Dobias J, Suvorova EI, Bernier-Latman R (2011) Role of proteins in controlling selenium nanoparticle size. Nanotechnology 22:195605

41. Xiong M, Long D, He H, Li Y, Li Y, Wang X (2014) Phosphatidylcholine synthesis is essential for HrpZ harpin secretion in plant pathogenic Pseudomonas syringae and non-pathogenic Pseudomonas sp. 593. Microbiol Res 169:196-204

42. Dhanjal S, Cameotra SS (2010) Aerobic biogenesis of selenium nanospheres by Bacillus cereus isolated from coalmine soil. Microb Cell Fact 9:52

43. Ike M, Takahashim K, Fujitam T, Kashiwa M, Fujita M (2000) Selenate reduction by bacteria ioslated from aquatic environment free from selenium contamination. Water Res 34(11):3019-3025

44. Kessi J, Ramuz M, Wehrli E, Spycher M, Bachofen R (1999) Reduction of selenite and detoxificat ion of elemental selenium by the phototrophic bacterium Rhodospirillum rubrum. Appl Environ Microbiol 65(11):4734-4740

45. Kessi J, Kurt WH (2004) Similarities between the abiotic reduction of selenite with glutathione and the dissimilatory reaction mediated by Rhodospirillum rubrum and Escherichia coli. J Biol Chem 279(49):50662-50669

46. Lampis S, Zonaro E, Bertolini C, Bernardi P, Butler CS, Vallini G (2014) Delayed formation of zero-valent selenium nanoparticles by Bacillus mycoides SeITE01 as a consequence of selenite reduction under aerobic conditions. Microb Cell Fact 13:35

47. Li D, Cheng Y, Wu C, Li W, Li N, Yang Z, Tong Z, Yu H (2014) Selenite reduction by Shewanella oneidensis MR-1 is mediated by fumarate reductase in periplasm. Sci Rep 4:3735. https://doi. org/10.1038/srep03735

48. Zhu J, Zuo W, Qin H, Feng Z, Zhen G, Su H (2008) An investigation on the source of soil Se in Yutangba Enshi: evidence from native selenium. Acta Mineral Sin 4:398-400

Publisher's Note Springer Nature remains neutral with regard to jurisdictional claims in published maps and institutional affiliations. 